\title{
EFEKTIFITAS POS BANTUAN HUKUM DI PENGADILAN (Studi Pada Posbakum Pengadilan Agama Sleman Tahun 2011-2012)
}

\author{
(The Effectiveness of Legal Aid Centre in Court \\ (Study in Posbakum Sleman Religious Court Year 2011-2012)) \\ Thalis Noor Cahyadi \\ Lembaga Bantuan Hukum Ansor Yogyakarta \\ Jl. HOS Cokroaminoto GG. Ngadimulyo,Yogyakarta \\ Email:tnc.lawyer@yahoo.co.id
}

Naskah diterima: 7 April 2013; revisi: 10 April 2013; disetujui:12 April 2013

\begin{abstract}
Abstrak
Dalam Surat Edaran Mahkamah Agung (SEMA) No. 10 Tahun 2010 mengamanahkan tentang pembentukan Pos Bantuan Hukum (Posbakum) di setiap pengadilan di bawah Mahkamah Agung (MA). Pengadilan Agama (PA) Sleman menjadi salah satu pilot project dalam pembentukan Posbakum, yang dimulai sejak 2011 dan berakhir 2012. Penyelenggaraan Posbakum di PA Sleman dirasakan sangat membantu masyarakat miskin dan bagi mereka yang tidak dapat memahami birokrasi pengadilan dan bagaimana memecahkan persoalan hukum. Namun, keberadaan Posbakum perlu diteliti mengenai bagaimana penyelenggaraan Posbakum di PA Sleman dan sejauhmana efektifitasnya dalam membantu masyarakat miskin untuk mengakses keadilan? Hasil penelitian menunjukkan bahwa penyelenggaraan Posbakum di PA Sleman selama 2011 hingga 2012 dapat berjalan dengan baik dan efektif. Data dari DPW APSI DIY dan LSBH UIN Yogyakarta menunjukkan bahwa lebih dari 1000 orang (1.272 orang) yang datang ke Posbakum PA Sleman mendapatkan layanan jasa bantuan hukum yang mereka butuhkan. Penelitian ini merekomendasikan untuk penyediaan anggaran bantuan yang lebih besar yang digunakan tidak hanya sebatas pemberian advis dan pembuatan berkas gugatan/permohonan saja, tetapi juga pada pendampingan perkara terutama perkara-perkara tertentu yang urgen seperti Kekerasan Dalam Rumah Tangga dan Perlindungan Anak. Selain itu penyelenggaraan bantuan hukum harus ditunjang oleh aturan main yang jelas yang tidak membuka tafsir liar sehingga membuat potensi adanya pemberian bantuan hukum yang salah sasaran.
\end{abstract}

Kata kunci: Posbakum, efektifitas, akses keadilan

\section{Abstract}

The mandate Seth forth in SEMA No. 10 Year 2010 is establishing legal aid centre (Posbakum) in any court which under the Supreme Court authority. Religious Court (PA) of Sleman becomes one of the pilot projects in the establishment POSBAKUM, which started since Year 2011 and ended in Year 2012. Implementation POSBAKUM in Religious Court Sleman is extremely helpful for poor society and those who could not understand how bureaucracy of court and how to resolve legal issues. Nevertheless, the existence of Posbakum needs to be researched as to how the implementation of Posbakum in PA Sleman and how far its effectiveness in helping the poor to access justice. The result of research showing that implementation of POSBAKUM at religious court Sleman during year 2011-2012 runs properly and effectively. Data from DPW APSI DIY and LSBH UIN Jogjakarta showing that more than 1000 people (1272 people) comes into POSBAKUM Religious court Sleman and obtain legal assistance services which they needed. This research recommends providing a larger aid budgets are used not only limited to giving advice and making the lawsuit/petition but also on mentoring cases, especially in certain matters such as domestic violence which urgent and child protection. Besides, implementations of legal aid have to support by clear rules that do not open to multi interpretation so that make a potential misdirected for legal assistance.

Keywords: Posbakum, effectiveness, access to justice 


\section{A. Pendahuluan}

Pembangunansuatunegaraseringkalidisertai dengan berbagai masalah yang melingkupinya, seperti kesenjangan akibat tidak meratanya pembangunan yang diikuti oleh minimnya akses keadilan karena persoalan ekonomi dan rendahnya tingkat pendidikan masyarakat. Kondisi tersebut semakin diperparah dengan minimnya kepedulian sesama masyarakat untuk bersikap saling membantu, karena telah tergerus oleh praktik-praktik individualime dan pragmatisme. Sementara pemerintah selaku penanggungjawab pengelola negara, nampak kerepotan mengurusi persoalan tersebut dan lebih tertarik pada program-program investasi pembangunan fisik. ${ }^{1}$

Persoalan yang banyak terlewatkan oleh pemerintah di tengah kesusahan masyarakat adalah minimnya akses mendapatkan keadilan hukum berupa bantuan hukum cuma-cuma atau gratis. Berbagai regulasi telah menuangkan kewajiban negara untuk memberikan bantuan hukum bagi masyarakat, antara lain Pasal 237 HIR yang mengatur tentang perkara prodeo, Undang-undang Nomor 8 Tahun 1981 tentang Hukum Acara Pidana (KUHAP) Pasal 54-60 juga diatur dalam BAB VII tentang Bantuan Hukum Pasal 69-74, Bab IV Pasal 22 Undang-undang Nomor 18 Tahun 2003 tentang Advokat, Peraturan Pemerintah Nomor 38 Tahun 2008 tentang Persyaratan dan Tata Cara Pemberian Bantuan Hukum.

Selain itu kewajiban memberikan bantuan hukum juga diatur dalam Bab VII Pasal 37-40 Undang-undang Nomor 4 Tahun 2004 tentang Kekuasaan Kehakiman yang kemudian diganti dengan Undang-undang Nomor 48 Tahun 2009 tentang Kekuasaan Kehakiman yang memuat ketentuan bantuan hukum dalam Bab XI Pasal 56-57. Undang-undang Nomor 49 Tahun 2004 tentang Perubahan Kedua Undang-undang Nomor 2 Tahun 1986 tentang Peradilan Umum juga mengatur tentang bantuan hukum sebagaimana tertera dalam Pasal 68 B dan 68 C, demikian pula dalam Undang-undang Nomor 50 Tahun 2009 tentang Perubahan Kedua Undang-undang Nomor 7 Tahun 1989 tentang Peradilan Agama juga disebutkan tentang pelayanan bantuan hukum oleh negara sebagaimana tersebut dalam Pasal 60 B dan 60 C serta Undang-undang Nomor 51 tahun 2009 tentang Perubahan Kedua atas Undang-undang Nomor 5 Tahun 1986 tentang Peradilan Tata Usaha Negara yakni Pasal 144 C dan 144 D.

Berbagai regulasi tersebut, pada praktiknya kurang bisa berjalan dengan baik. Bantuan hukum yang diberikan oleh negara melalui pengadilan lebih banyak menyangkut perkaraperkara pidana prodeo di mana terdakwa yang dikenai ancaman pidana 5 (lima) tahun atau lebih namun tidak mampu menyewa penasehat hukum maka Pengadilan menunjuk penasehat hukum untuk memberi bantuan secara cumacuma, sebagaimana amanah Pasal 56 KUHAP, sementara untuk perkara-perkara di luar pidana sangatlah terbatas. Padahal persoalan hukum terkait dengan akses keadilan hukum, tidak saja menyangkut persoalan-persoalan tindak pidana, melainkan juga permasalahan-permasalahan keperdataan yang justru banyak menghimpit masyarakat miskin.

Penyelesaian permasalahan hukum tidak selalu diselesaikan melalui jalur peradilan. Masyarakat awam pada dasarnya lebih

T. Mulya Lubis, "Bantuan Hukum: Arti dan Peranannya," Prisma No. 6 Tahun II, Desember (1973). 
menginginkan penyelesaian di luar pengadilan dengan harapan hal tersebut dapat lebih cepat terselesaikan. Demikian pula dengan ketidakfahaman masyarakat tentang prosedur pengurusan berbagai dokumen hukum baik berupa dokumen kepemilikan, perijinan, dan lain sebagainya yang tentunya membutuhkan pencerahan berupa konsultasi atau nasehatnasehat hukum yang dapat membantu mereka. Akan tetapi pada faktanya, kebutuhankebutuhan tersebut belum tersentuh secara merata.

Lahirnya Undang-Undang Nomor 48 Tahun 2009 tentang Kekuasaan Kehakiman, UndangUndang Nomor 49 Tahun 2004 tentang Perubahan Kedua Undang-Undang Nomor 2 Tahun 1986 tentang Peradilan Umum, UndangUndang Nomor 50 Tahun 2009 tentang Perubahan Kedua Undang-undang Nomor 7 Tahun 1989 tentang Peradilan Agama serta Undang-Undang Nomor 51 Tahun 2009 tentang Perubahan Kedua atas Undang-Undang Nomor 5 Tahun 1986 tentang Peradilan Tata Usaha Negara menjadi angin segar bagi masyarakat miskin, karena di dalam undang-undang tersebut secara tegas disebutkan bahwa setiap orang yang tersangkut perkara berhak memperoleh bantuan hukum. Negara menanggung biaya perkara bagi pencari keadilan yang tidak mampu. Pihak yang tidak mampu harus melampirkan surat keterangan tidak mampu dari kelurahan tempat domisili yang bersangkutan.

Selanjutnya undang-undang di atas juga memerintahkan pada setiap pengadilan negeri, pengadilan agama dan pengadilan tata usaha negara untuk dibentuk pos bantuan hukum untuk pencari keadilan yang tidak mampu dalam memperoleh bantuan hukum. Bantuan hukum diberikan secara cuma-cuma kepada semua tingkat peradilan sampai putusan terhadap perkara tersebut mempunyai kekuatan hukum tetap.

Implementasi ketentuan bantuan hukum ini bukanlah perkara mudah, karena hal ini terkait dengan pendanaan, terlebih terkait dengan perkara-perkara perdata yang mengandung aspek-aspek finansial yang tidak sedikit, karena pada prinsipnya proses beracara perdata membutuhkan dana, mulai dari biaya pendaftaran, panjar panggilan-panggilan para pihak, leges dalam pembuktian, dan pengambilan putusan, terlebih manakala perkara tersebut membutuhkan penyitaan (beslag) dan eksekusi putusan terhadap suatu obyek sengketa yang tidak bisa diselesaikan secara sukarela, tentu begitu banyak dana yang harus dikeluarkan.

Berbagai masalah di atas nampaknya tidak mungkin dipenuhi oleh negara sejauh dalam konteks perundangan di atas. Mendasarkan hal tersebut, Mahkamah Agung memberikan batasan-batasan bantuan hukum terutama dalam hubungannya dengan pembentukan Pos Bantuan Hukum sebagaimana diamanahkan oleh undang-undang dengan menerbitkan Surat Edaran Mahkamah Agung (SEMA) Nomor 10 Tahun 2010 tertanggal 30 Agustus 2010 tentang Pedoman Pemberian Bantuan Hukum.

Selain memuat pengertian dan tujuan bantuan hukum, dalam SEMA tersebut memuat ketentuan tentang penyelenggaraan Pos Bantuan Hukum (Posbakum) di masing-masing pengadilan yakni Pengadilan Negeri (PN), Pengadilan Agama (PA) dan Pengadilan Tata Usaha Negara (PTUN).

Pembentukan Posbakum berdasarkan SEMA tersebut tidak serta merta dapat dilakukan di pengadilan-pengadilan di tiga lingkungan di atas (PN, PA, dan PTUN). Oleh karenanya Mahkamah Agung menerapkan sistem uji coba pelaksanaan pembentukan Posbakum dengan 
pilot project dilaksanakan oleh Badan Peradilan Agama (Badilag MA) melalui PA-PA yang telah ditentukan di Indonesia.

Salah satu Pengadilan Agama yang dijadikan pilot project penyelenggaraan Posbakum adalah Pengadilan Agama Sleman, Daerah Istimewa Yogyakarta. Posbakum di Pengadilan Agama Sleman pertama kali dilaksanakan pada bulan April 2011 sampai dengan Desember 2011, yang dilanjutkan pada tahun kedua yakni tahun 2012 yang dimulai pada bulan April 2012 hingga Desember 2012.

Posbakum di Pengadilan Agama Sleman diselenggarakan bekerjasama dengan Dewan Pengurus Wilayah Asosiasi Pengacara Syariah Indonesia (DPW APSI) Daerah Istimewa Yogyakarta dan Lembaga Studi dan Bantuan Hukum (LSBH) Fakultas Syariah dan Hukum Universitas Islam Negeri (UIN) Sunan Kalijaga Yogyakarta.

Penyelenggaraan Posbakum di Pengadilan Agama Sleman selama 2011 hingga 2012 dirasakan sangat membantu masyarakat yang tidak mampu dan tidak memahami birokrasi peradilan dan teknik penyelesaian masalah. Namun demikian, evaluasi penyelenggaran Posbakum di Pengadilan Agama Sleman perlu juga dilakukan dengan mengukur tingkat efektifitasnya dalam mengimplementasikan tujuan-tujuan yang telah diamanahkan oleh peraturan perundang-undangan yang berlaku terutama terkait dengan SEMA Nomor 10 tahun 2010.

Penelitian ini akan melihat bagaimana sesungguhnya efektifitas pos bantuan hukum dalam membantu masyarakat yang tidak mampu untuk mengakses keadilan dengan biaya ringan di Pengadilan Agama Sleman Daerah Istimewa Yogyakarta.

\section{B. Permasalahan}

Berdasarkan latar belakang di atas, dapat disusun rumusan masalah sebagai berikut:

1. Bagaimanakah penyelenggaraan Pos Bantuan Hukum (Posbakum) di Pengadilan Agama Sleman?

2. Sejauhmana efektifitas penyelenggaraan Pos Bantuan Hukum (Posbakum) di Pengadilan Agama Sleman dalam membantu masyarakat yang tidak mampu untuk mengakses keadilan?

Untuk mengukur sejauhmana efetifitas di sini dibatasi pada indikator jumlah (quantity) dari masyarakat pengguna jasa bantuan hukum yang datang di Posbakum PA Sleman.

\section{Metode Penelitian}

Penelitian ini merupakan suatu penelitian empiris yang menitik beratkan pada studi lapangan (field study) guna mendapatkan data primer. Dan untuk menunjangnya dilakukan studi kepustakaan (literature study) untuk mendapatkan data skunder. Laporan hasil penelitian ini bersifat deskriptif analitis (descriptive analytics), artinya laporannya mendiskripsikan fakta-fakta empiris di lapangan dengan menggunakan analisa normatif (normative analytics) sehingga fakta-fakta tersebut memiliki makna dan kaitan dengan permasalahan yang diteliti. Dari penelitian ini diharapkan dapat memberikan gambaran secara rinci dan sistematis tentang permasalahan empiris di lapangan dan akhirnya menemukan solusi berdasarkan data yang diperoleh.

\section{Lokasi penelitian}

Penelitian ini dilakukan di Posbakum Pengadilan Agama Sleman, yang beralamat di Jalan Parasamya, Beran, Tridadi, Sleman, Daerah Istimewa Yogyakarta. 


\section{Cara Pengumpulan Data}

Cara pengumpulan data dalam penelitian studi lapangan ini adalah dengan melakukan wawancara yang tidak terstruktur (nonstructured interview) kepada narasumber, yakni wawancara yang hanya memuat garis besar tentang hal yang akan ditanyakan, seperti berapa jumlah dan jenis perkara yang dilayani dan berapa masyarakat yang dilayani berdasarkan jenis kelamin. Pertanyaan-pertanyaan tersebut selanjutnya dikembangkan sendiri oleh peneliti dengan teknik wawancara bebas guna mendapatkan data yang dibutuhkan. Adapun narasumberyang diwawancarai adalah Pengurus DPW APSI DIY, Direktur LSBH UIN Yogyakarta, Wakil Ketua Pengadilan Agama Sleman dan beberapa konsultan hukum di Posbakum PA Sleman.

\section{Analisis Data}

Seluruh data primer dan sekunder yang diperoleh dari studi lapangan dan kepustakaan diklasifikasikan dan disusun secara sistematis, sehingga dapat dijadikan acuan dalam melakukan analisis. Langkah selanjutnya, dari data primer dan data sekunder yang telah disusun dan ditetapkan sebagai sumber dalam penyusunan penelitian ini kemudian dianalisa secara kualitatif dengan menggunakan metode diskriptif (descriptive method).

Analisa kualitatif yakni metode analisis data yang mengelompokkan data yang diperoleh dari studi lapangan menurut kualitas dan kebenarannya kemudian dikorelasikan dengan teori-teori yang diperoleh dari studi kepustakaan sehingga akan didapatkan jawaban atas permasalahan. Sementara metode deskriptif yakni metode analisis dengan memilih data yang menggambarkan keadaan sebenarnya di lapangan.

\section{Pembahasan}

\section{Bantuan Hukum dalam Perkara Perdata Agama}

Menurut Pasal 1 Undang-Undang Nomor 16 Tahun 2011, bantuan hukum adalah jasa hukum yang diberikan oleh Pemberi Bantuan Hukum secara cuma-cuma kepada Penerima Bantuan Hukum. Sementara Lampiran B Pasal 1 Ketentuan Umum dalam SEMA Nomor 10 Tahun 2010 disebutkan bantuan hukum adalah pemberian jasa hukum yang difasilitasi oleh negara melalui Peradilan Agama, baik dalam perkara perdata gugatan dan permohonan maupun perkara jinayat. Bantuan hukum dalam perkara perdata meliputi pelayanan perkara prodeo, penyelenggaraan sidang keliling dan penyediaan Pos Bantuan Hukum di Pengadilan Agama secara cuma-cuma bagi masyarakat yang tidak mampu. Bantuan hukum dalam perkara jinayat melalui penyediaan Pos Bantuan Hukum dan Advokat Pendamping di Mahkamah Syar'iyah secara cuma-cuma bagi masyarakat yang tidak mampu.

Bantuan hukum bertujuan: Pertama, membantu masyarakat pencari keadilan yang tidak mampu secara ekonomis dalam menjalankan proses hukum di pengadilan. Kedua, meningkatkan akses terhadap keadilan. Ketiga, meningkatkan kesadaran dan pengetahuan masyarakat tentang hukum melalui penghargaan, pemenuhan dan perlindungan hukum terhadap hak dan kewajibannya, dan keempat memberikan pelayanan prima kepada masyarakat pencari keadilan.

Bantuan hukum dalam perkara perdata agama berwujud pelayanan perkara prodeo, penyelenggaraan sidang keliling dan pos bantuan hukum. Prodeo adalah proses berperkara di pengadilan secara cuma-cuma dengan dibiayai negara melalui DIPA pengadilan. Sementara 
sidang keliling adalah sidang yang dilaksanakan secara tetap (berkala) atau sewaktu-waktu oleh pengadilan di suatu tempat yang ada di dalam wilayah hukumnya tetapi di luar tempat kedudukan pengadilan.

\section{Penyelenggaraan Pos Bantuan Hukum (Posbakum) di Pengadilan Agama Sleman.}

\section{a. Teknis Penyelenggaran Posbakum di Pengadilan Agama Sleman}

Sebelum diselenggarakan Posbakum dengan bekerjasamadengan pihak lain, Pengadilan Tinggi Agama (PTA) Yogyakarta melakukan sosialisasi tentang SEMA Nomor 10 tahun 2010 pada tanggal 22 Maret 2011 dengan mengundang sejumlah lembaga bantuan hukum kampus, lembaga swadaya masyarakat dan organisasi advokat, di antaranya PKBH UMY, LSBH FSH UIN Sunan Kalijaga, LBH Ansor, Rifka Annisa dan Asosiasi Pengacara Syariah Indonesia (APSI).

Setelah sosialisasi, Pengadilan Agama Sleman kemudian mengumumkan kepada publik, tentang kesempatan bekerjasama dalam penyelenggaraan Posbakum di Pengadilan Agama Sleman, dengan menempel di papan pengumuman di kantor Pengadilan Agama Sleman serta dengan memasukkan pada website Pengadilan Agama Sleman yakni www. pa-slemankab.go.id. Dari hasil pengumuman yang dilakukan kurang lebih satu bulan, hanya dua lembaga yang mengajukan permohonan kerjasama penyelenggaraan Posbakum di Pengadilan Agama Sleman, yakni Dewan Pengurus Wilayah Asosiasi Pengcara Syariah Indonesia (DPW APSI) D.I. Yogyakarta dan Lembaga Studi dan Bantuan Hukum (LSBH) Fakultas Syariah dan Hukum (FSH) UIN Sunan Kalijaga Yogyakarta.
Berdasarkan penilaian terhadap persyaratan yang diajukan kedua lembaga tersebut, maka keduanya dinyatakan lolos seleksi untuk kemudian membuat Nota Kesepahaman (Memorandum of Understanding) berupa Perjanjian Kerjasama antara Pengadilan Agama Sleman dengan DPW APSI DIY dan LSBH FSH UIN Sunan Kalijaga Yogyakarta. Perjanjian kerjasama tersebut ditanda tangani tanggal 24 Maret 2011 oleh Ketua Pengadilan Agama Sleman dan Ketua DPW APSI DIY serta Direktur LSBH FSH UIN Sunan Kalijaga Yogyakarta.

Penyelenggaraan Posbakum Pengadilan Agama Sleman kemudian mulai dilaksanakan pada 4 April 2011, dan secara formil berlangsung hinggatanggal19Desember2011, meskipunpada praktiknya para Konsultan Hukum di Posbakum Pengadilan Agama Sleman menggenapkan waktunya hingga tanggal 29 Desember 2011. Demikian pula penyelenggaraan Posbakum pada tahun kedua berlangsung secara formil mulai 3 April 2012 hingga 27 Desember 2012.

Pihak Pengadilan Agama Sleman menyediakan dua ruang khusus untuk penyelenggaraan Posbakum serta memasang spanduk sosiasiliasi penyelenggaraan Posbakum di Pengadilan Agama Sleman.

DPW APSI DIY dan LSBH FSH UIN Sunan Kalijaga Yogyakarta sebagai pelaksana Posbakum masing-masing menerjunkan dua orang konsultannya setiap hari Senin hingga Kamis mulai jam 09.00 WIB - 13.00 WIB untuk melayani masyarakat pencari keadilan di Pengadilan Agama Sleman.

Secara normatif jenis pelayanan Posbakum Pengadilan Agama Sleman mengacu pada SEMA Nomor 10 tahun 2010, di mana Jenis jasa hukum yang diberikan oleh Posbakum berupa pemberian informasi, konsultasi, advis dan pembuatan surat gugatan/permohonan. Jenis 
jasa hukum tersebut dapat diberikan kepada penggugat/pemohon dan tergugat/termohon. Pemberian jasa hukum kepada penggugat/ pemohon dan tergugat/termohon tidak boleh dilakukan oleh satu orang pemberi bantuan hukum yang sama.

Sementara yang berhak menerima jasa dari Posbakum adalah orang yang tidak mampu membayar jasa advokat terutama perempuan dan anak-anak serta penyandang disabilitas sesuai peraturan perundang-undangan yang berlaku, baik sebagai penggugat/permohon maupun tergugat/termohon.

Berdasarkan SEMA Nomor 10 Tahun 2010, masyarakat yang akan meminta jasa hukum di Posbakum harus memenuhi persyaratan yakni dengan mengajukan permohonan pemberian jasa dari Posbakum dengan melampirkan:

1) Surat Keterangan Tidak Mampu (SKTM) yang dikeluarkan oleh Kepala Desa/Lurah/Banjar/ Nagari/Gampong; atau

2) Surat Keterangan Tunjangan Sosial lainnya seperti Kartu Keluarga Miskin (KKM), Kartu Jaminan kesehatan Masyarakat (Jamkesmas), Kartu Program Keluarga Harapan (PKH), dan Kartu Bantuan Langsung Tunai (BLT); atau

3) Surat Pernyataan tidak mampu membayar jasa advokat yang dibuat dan ditandatangani oleh Pemohon Bantuan Hukum dan diketahui oleh Ketua Pengadilan Agama.

Namun demikian pada praktiknya di Posbakum Pengadilan Agama Sleman, syarat sebagaimana poin 2) dan 3) sulit untuk diimplementasikan. Berdasarkan hasil evaluasi yang ada, Pengadilan Agama Sleman lebih menafsirkan syarat ketidakmampun tersebut tidak saja dalam arti tidak mampu secara ekonomi, tetapi lebih luas dari itu, tidak mampu harus dimaknai ketidakmampuan membuat permohonan/gugatan dalam perkara yang menjadi kewenangan absolut Peradilan Agama. Sehingga pada praktiknya semua masyarakat yang datang ke Posbakum Pengadilan Agama Sleman selama mengisi formulir permohonan dan membuat pernyataan tidak mampu membayar jasa advokat akan tetap dilayani, dengan demikian praktikPosbakum diPengadilan Agama Sleman tidak terbatas pada orang miskin tetapi semua lapisan masyarakat yang membutuhkan jasa hukum berupa pemberian informasi, konsultasi, advis dan pembuatan surat gugatan/permohonan. Secara normatif hal ini bertentangan dengan persyaratan yang tercantum dalam SEMA Nomor 10 tahun 2010 maupun tujuan pemberian bantuan hukum itu sendiri.

\section{b. Jumlah Jasa Hukum yang telah diberikan di Posbakum Pengadilan Agama Sleman tahun 2011-2012}

Penyelenggaraan Posbakum di Pengadilan Agama Sleman pada faktanya banyak mendapat respon dari masyarakat pencari keadilan di wilayah Kabupaten Sleman. Hal ini ditunjukkan data yang dimiliki oleh Pelaksana teknis Posbakum yakni DPW APSI DIY dan LSBH FSH UIN Sunan Kalijaga Yogyakarta, baik pada tahun pertama yakni 2011 maupun tahun kedua 2012. Berdasarkan data yang diperoleh dari kedua lembaga tersebut menunjukkan bahwa selama tahun 2011 Posbakum Pengadilan Agama Sleman telah memberikan layanan jasa hukum kepada masyarakat sebanyak 699 orang, dengan rincian berdasarkan jenis kelamin, laki-laki sebanyak 186 orang dan perempuan sebanyak 513 orang. 


\section{Tabel.1}

Jumlah Penerima Jasa Hukum di Posbakum PA. SLeman berdasarkan Jenis Kelamin tahun 2011

\begin{tabular}{|c|c|}
\hline Jenis Kelamin & Jumlah \\
\hline Laki-laki & 186 \\
\hline Perempuan & 513 \\
\hline TOTAL & 699 \\
\hline
\end{tabular}

Sumber: diolah dari Laporan Posbakum DPW APSI DIY dan LSBH tahun 2011

Sementara pada tahun 2012 jumlah masyarakat yang dilayani oleh Posbakum Pengadilan Agama Sleman sebanyak 873 orang, dengan rincian laki-laki sejumlah 320 orang dan perempuan sejumlah 553 orang.

\section{Tabel.2}

Jumlah Penerima Jasa Hukum di Posbakum PA. SLeman berdasarkan Jenis Kelamin tahun 2012

\begin{tabular}{|c|c|}
\hline Jenis Kelamin & Jumlah \\
\hline Laki-laki & 320 \\
\hline Perempuan & 553 \\
\hline TOTAL & 873 \\
\hline
\end{tabular}

Sumber: diolah dari Laporan Posbakum DPW APSI DIY dan LSBH tahun 2012

Adapun jenis dan jumlah jasa hukum yang telah dilayani oleh Posbakum Pengadilan Agama Sleman pada tahun 2011 adalah konsultasi sebanyak 51 orang, serta pembuatan permohonan dan surat gugatan, berupa: permohonan cerai talak sebanyak 159 orang, gugatan perceraian (cerai gugat) sebanyak 479 orang, permohonan ijin poligami sebanyak 1 orang, surat gugatan cerai gugat dan hadhanah sebanyak 5 orang, permohonan cerai talak dan hadhanah sebanyak 2 orang dan permohonan dispensasi nikah sebanyak 2 orang.
Tabel.3

Jenis dan Jumlah Jasa Hukum di Posbakum P.A. Sleman tahun 2011

\begin{tabular}{|c|l|c|}
\hline No & \multicolumn{1}{|c|}{ Jenis Jasa Hukum } & Jumlah \\
\hline 1 & Konsultasi & 51 \\
\hline 2 & Membuat Permohonan Cerai Talak & 159 \\
\hline 3 & $\begin{array}{l}\text { Membuat Permohonan Cerai Talak dan } \\
\text { Hadhanah }\end{array}$ & 2 \\
\hline 4 & $\begin{array}{l}\text { Membuat Surat Gugatan Cerai (Cerai } \\
\text { Gugat) }\end{array}$ & 479 \\
\hline 5 & $\begin{array}{l}\text { Membuat Surat Gugatan Cerai (Cerai } \\
\text { Gugat) dan Hadhanah }\end{array}$ & 5 \\
\hline 6 & Membuat Permohonan izin Poligami & 1 \\
\hline 7 & Membuat Permohonan Dispensasi Nikah & 2 \\
\hline \multicolumn{2}{|c|}{ TOTAL } & 699 \\
\hline
\end{tabular}

Sumber: diolah dari Laporan Posbakum DPW APSI DIY dan LSBH tahun 2011

Pada tahun 2012, jenis dan jumlah jasa hukum yang telah dilayani oleh Posbakum Pengadilan Agama Sleman adalah konsultasi sejumlah 74 orang, pembuatan permohonan cerai talak sebanyak 225 orang, cerai gugat sebanyak 542 orang, cerai gugat dan hadhanah sebanyak 1 orang, permohonan ijin poligami 5 orang, permohonan pembatalan nikah 4 orang, permohonan dispensasi nikah 1 orang, permohonan wali adhol 3 orang, permohonan pengangkatan anak 1 orang dan permohonan penetapan ahli waris 1 orang.

\section{Tabel.4}

Jenis dan Jumlah Jasa Hukum di Posbakum P.A. Sleman tahun 2012

\begin{tabular}{|c|l|c|}
\hline No & \multicolumn{1}{|c|}{ Jenis Jasa Hukum } & Jumlah \\
\hline 1 & Konsultasi & 74 \\
\hline 2 & Membuat Permohonan Cerai Talak & 225 \\
\hline 3 & $\begin{array}{l}\text { Membuat Surat Gugatan Cerai (Cerai } \\
\text { Gugat) }\end{array}$ & 542 \\
\hline 4 & $\begin{array}{l}\text { Membuat Surat Gugatan Cerai (Cerai } \\
\text { Gugat)dan Hadhanah }\end{array}$ & 1 \\
\hline 5 & Membuat Permohonan ljin Poligami & 5 \\
\hline 6 & Membuat Permohonan Pembatalan Nikah & 4 \\
\hline 7 & Membuat Permohonan Dispensasi Nikah & 1 \\
\hline 8 & Membuat Permohonan Wali Adhol & 3 \\
\hline
\end{tabular}




\begin{tabular}{|c|l|c|}
\hline 9 & $\begin{array}{l}\text { Membuat Permohonan Pengangkatan } \\
\text { Anak }\end{array}$ & 1 \\
\hline 10 & $\begin{array}{l}\text { Membuat Permohonan Penetapan Ahli } \\
\text { Waris }\end{array}$ & 1 \\
\hline \multicolumn{2}{|c|}{ TOTAL } & 873 \\
\hline
\end{tabular}

Sumber: diolah dari Laporan Posbakum DPW APSI DIY dan LSBH tahun 2012

Mencermati data di atas menunjukkan bahwa masyarakat cukup antusias dengan keberadaan Posbakum di Pengadilan Agama Sleman terutama bagi mereka yang memang tidak memahami bagaimana prosedur pembuatan berkas persidangan dalam perkara perdata agama, maupun bagi mereka yang memang 'buta' terhadap hukum.

Namun demikian, jika dikaitkan kembali dengan tujuan bantuan hukum, data-data tersebut juga dapat menunjukkan bahwa ada hal-hal yang nampaknya bertentangan dengan hakikat bantuan hukum sebagaimana tercantum dalam SEMA Nomor 10 tahun 2010. Sebagaimana diketahui bahwa tujuan bantuan hukum dalam SEMA tersebut adalah:

1) membantu masyarakat pencari keadilan yang tidak mampu secara ekonomis dalam menjalankan proses hukum di pengadilan.

2) meningkatkan akses terhadap keadilan.

3) meningkatkan kesadaran dan pengetahuan masyarakat tentang hukum melalui penghargaan, pemenuhan dan perlindungan hukum terhadap hak dan kewajibannya, dan

4) memberikan pelayanan prima kepada masyarakat pencari keadilan.

Merujuk data di atas, di mana ada perkara pengajuan permohonan ijin poligami, perkara tersebut dikaitkan dengan tujuan bantuan hukum dalam rangka membantu masyarakat pencari keadilan yang tidak mampu secara ekonomis dalam menjalankan proses hukum di pengadilan, patut dipertanyakan, karena dalam perkara poligami, disyaratkan mampu berbuat adil baik secara batiniah maupun lahiriah termasuk syarat kemampuan ekonomi yang lebih dari pemohon, sehingga menjadi wajar jika ada pertanyaan bukankah lelaki yang mengajukan poligami itu orang yang mampu secara ekonomi?. Lalu bagaimana bisa perkara permohonan poligami dibantu oleh Posbakum?

Pertanyaan tersebut cukup beralasan mengingat Posbakum dibentuk pada dasarnya untuk membantu masyarakat yang tidak mampu secara ekonomi dalam menjalani proses hukum. Fakta ini tentu harus menjadi masukan bagi keberlanjutan program bantuan hukum di masa akan datang, sehingga program bantuan hukum yang dibiayai oleh pajak masyarakat tidak menjadi salah sasaran.

\section{Efektifitas Posbakum di Pengadilan Agama Sleman}

Secara etimologi kata efektivitas berasal dari kata efektif dalam bahasa Inggris "effective", yang telah mengintervensi ke dalam bahasa Indonesia dan memiliki makna "berhasil", dalam bahasa Belanda "effectief" memiliki makna "berhasil guna". Sedangkan efektivitas aturan secara tata bahasa dapat diartikan sebagai keberhasil-gunaan hukum, dalam hal ini berkenaan dengan keberhasilan pelaksanaan aturan itu sendiri. Efektifitas merupakan suatu kegiatan yang memperlihatkan suatu strategi perumusan masalah yang bersifat umum,

Soerjono Soekanto, Suatu Tinjauan Sosiologi Hukum Terhadap Masalah-Masalah Sosial (Bandung: Alumni, 1980), hlm. 176. 
yaitu perbandingan realitas hukum dan ideal hukum².

Secara khusus terlihat jenjang antara aturan dalam tindakan (rule in action) dengan aturan dalam teori (rule in theory). Menurut Soekanto, efektifitas aturan adalah pengaruh aturan terhadap masyarakat, inti dari pengaruh aturan terhadap masyarakat adalah prilaku warga masyarakat yang sesuai dengan aturan yang berlaku. Kalau masyarakat berprilaku sesuai dengan yang diharapkan atau yang dikendaki oleh aturan, maka dapat dikatakan bahwa aturan yang bersangkutan adalah efektif. ${ }^{3}$

Untuk menggambarkan efektifitas suatu program dapat dilihat skema berikut ini:

\section{Skema 1}

Indikator Efektfitas Program

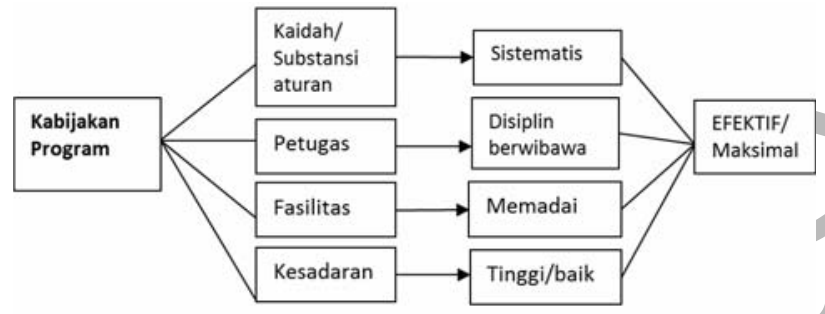

Skema ini menunjukkan bahwa suatu kebijakan program paling tidak memuat empat elemen, yakni subtansi aturan itu sendiri (policy substance), petugas yang melaksanakan, fasilitas yang ada dan kesadaran yang terjadi. Suatu kebijakan akan dikatakan efektif manakala dalam kebijakan tersebut memuat subtansi atau kaidah aturan yang jelas dan sistematis, petugasnya disiplin dan berwibawa dalam menjelankan kebijakan, fasilitas yang dimiliki memadai dan menunjang, serta adanya kesadaran yang baik dari stakeholder yang ada. ${ }^{4}$
Dalam konteks program Posbakum, kebijakan yang ada secara teknis mengacu pada aturan yang tertera dalam SEMA Nomor 10 tahun 2010, yang secara aplikatif dilaksanakan melalui perjanjian kerjasama antara instansi penyelenggara Posbakum dengan organisasi atau lembaga yang menangani secara teknis, meskipun perjanjian tersebut juga harus mengacu pada SEMA Nomor 10 tahun 2010, terutama pada Lampiran B yang ditujukan untuk Pengadilan Agama.

Secara substansi, SEMA Nomor 10 tahun 2010 Lampiran B, secara detail telah mengatur prosedur dan proses pemberian bantuan hukum, siapa yang bisa menjadi pemberi dan penerima bantuan hukum dan lain sebagainya, sehingga dapat dikatakan bahwa SEMA Nomor 10 Tahun 2010 secara substansi cukup memadai.

Sementara dalam tataran aplikasinya terkait dengan petugas pelaksananya, Posbakum Pengadilan Agama Sleman telah berupaya dengan baik memilih organisasi atau lembaga yang memang memiliki sumber daya manusia yang mencukupi, baik dari kuantitas maupun kualitas kapasitas untuk menjadi pemberi bantuan hukum yang memberikan jasa hukum kepada masyarakat yang memerlukannya. Asosiasi Pengacara Syariah Indonesia (APSI) merupakan salah satu organisasi advokat yang tercantum dalam Undang-undang Nomor 18 tahun 2003 tentang Advokat, yang mayoritas pengurus dan anggotanya adalah alumni Fakultas Syariah PTAI yang secara keilmuan memahami persoalan-persoalan seputar hukum Islam terutama terkait perkara-perkara yang menjadi kewenangan Pengadilan Agama. Sedangkan Lembaga Studi dan Bantuan Hukum

Ibid., hlm. 62.

4 Thalis Noor Cahyadi, Siginifikansi Ombudsman dalam Penegakan Bisnis Beretika dan Berkelanjutan (Studi pada Lembaga Ombudsman Swasta DIY), (Yogyakarta: Riset Sekolah Pascasarjana UGM Yogyakarta, 2010), hlm. 152. 
(LSBH) Fakultas Syariah dan Hukum (FSH) UIN Sunan Kalijaga Yogyakarta merupakan lembaga bantuan hukum kampus yang sebagian besar pengurusnya adalah para dosen dan tenaga pengajar kampus yang secara teoritis dan praktis menguasai materi keperdataan agama. LSBH dibentuk dalam rangka menjalankan fungsi pengabdian masyarakat sebagai bagian dari Tri Dharma Perguruan Tinggi.

Mendasarkan hal demikian, maka secara aplikatif petugas yang diamanahi menjalankan Posbakum di Pengadilan Agama Sleman cukup memiliki kapasitas yang baik. Kondisi ini juga ditunjukkan bahwa sampai Posbakum berakhir tidak ada keluhan dari masyarakat yang meminta pelayanan di Posbakum, baik dari sisi pelayanan maupun advis yang disampaikan. Hal ini menjadi indikator bahwa pelayanan oleh para konsultan hukum di Posbakum Pengadilan Agama Sleman cukup maksimal dan memuaskan.

Melihat dari aspek fasilitas yang ada dalam program Posbakum di Pengadilan Agama Sleman juga cukup memadai. Pihak Pengadilan Agama Sleman menyediakan 2 (dua) ruang khusus bagi Posbakum yakni ruang untuk DPW APSI DIY dan ruang untuk LSBH FSH UIN Sunan Kalijaga Yogyakarta. Di setiap ruangan juga telah disediakan 2 (dua) buah meja dan kursi serta (1) satu kipas angin dan satu (1) almari untuk menyimpan berkas. Sementara pihak DPW APSI DIY dan LSBH LSBH FSH UIN Sunan Kalijaga Yogyakarta menyediakan alat tulis berupa Lap Top, printer dan kertas. Ketersediaan fasilitas ini membuat masyarakat pencari keadilan merasa cukup nyaman. Hingga Posbakum berakhirpun tidak ada ditemukan masyarakat yang mengeluh tentang fasilitas yang disediakan.

Kondisi tersebut ternyata juga didukung oleh kesadaran masyarakat untuk memanfaatkan layanan Posbakum Pengadilan Agama Sleman dengan baik. Masyarakat yang membutuhkan layanan Posbakum Pengadilan Agama bersedia mengantri dengan tertib. Para konsultan pun juga secara suka rela bersedia memanjangkan waktu layanan, dalam arti tidak kaku sesuai aturan main yakni dimulai pukul $09.00-12.00$ WIB tetapi pada praktiknya para konsultan bersedia memberikan layanan hingga pukul 13.00 WIB atau 13.30 WIB.

Mencermatiuraian diatas, dapat disimpulkan bahwa Posbakum di Pengadilan Agama Sleman dapat berjalan secara efektif, dalam arti bahwa tujuan-tujuan bantuan hukum sebagaimana diamanahkan oleh SEMA Nomor 10 tahun 2010 terutama dalam hal meningkatkan akses terhadap keadilan, meningkatkan kesadaran dan pengetahuan masyarakat tentang hukum melalui penghargaan, pemenuhan dan perlindungan hukum terhadap hak dan kewajibannya, dan memberikan pelayanan prima kepada masyarakat pencari keadilan. Dengan demikian pada faktanya keberadaan Posbakum di Pengadilan Agama Sleman tidak saja dirasakan sangat membantu masyarakat pencari keadilan, tetapi juga memperingan tugas administratif Pengadilan Agama Sleman, karena dengan adanya Posbakum tugas Meja Satu yang selama ini dibebani selain menerima pendaftaran gugatan/permohonan juga dibebani untuk mendengarkan dan mengetikkan gugatan/permohonan bagi penggugat/pemohon yang tidak bisa mengetik karena buta huruf atau mereka yang tidak mengerti bagaimana membuat gugatan/permohonan. Adanya Posbakum dirasa juga membantu mengurangi beban mereka, karena tugas pembuatan gugatan/permohonan diserahkan sepenuhnya kepada Posbakum.

Adanya kebijakan untuk menghentikan sementara kegiatan Posbakum karena telah 
berlakunya Undang-undang Nomor 16 tahun 2011 tentang Bantuan Hukum, yang kemudian mengambil alih kegiatan Posbakum yang dahulunya di bawah Mahkamah Agung beralih kepada Kementerian Hukum dan HAM, justru menjadi hambatan bagi keberlangsungan Posbakum di Pengadilan Agama Sleman yang telah berjalan dengan baik dan efektif. Sehingga banyak masyarakat yang mempertanyakan ditiadakannya Posbakum, karena bagi mereka Posbakum sangat membantu mereka dalam memecahkan persoalan hukum terkait dengan perkara-perkara perdata agama.

Lahirnya Undang-undang Bantuan Hukum seyogyanya tidak secara serta merta meniadakan peranan lembaga-lembaga di bawah Mahkamah Agung dalam menyelenggarakan kegiatan bantuan hukum seperti Posbakum di Pengadilan Agama Sleman. Kementerian Hukum dan HAM seharusnya mempertimbangkan kegiatan Posbakum yang telah berjalan di beberapa Pengadilan di bawah MA dengan tetap mempertahankan keberadaan mereka. Peralihan anggaran dari Mahkamah Agung ke Kementerian Hukum dan HAM seharusnya tidak otomatis menghapus Posbakum yang telah berjalan. Kementerian Hukum dan HAM meskipun memegang anggaran tetapi tetap dapat menyerahkan teknis penyelenggaraan pemberian bantuan hukum yang bersifat litigasi kepada Pengadilan-pengadilan di bawah Mahkamah Agung, karena bagaimanapun pengadilan-pengadilan itulah yang mengetahui bagaimana dan sejauhmana kebutuhan bantuan hukum bagi masyarakat pencari keadilan, terlebih mereka telah lama bekerjasama dengan organisasi-organisasi bantuan hukum, baik LSM, LBH maupun Organisasi Advokat.Kementerian Hukum dan HAM dapat mengambil peranan aktif secara penuh di bidang penyelenggaraan bantuan hukum yang bersifat advokasi di luar pengadilan (non litigasi) dengan bekerjasama dengan organisasi-organisasi bantuan hukum. Adanya program verifikasi dan akreditasi organisasi bantuan hukum yang diselenggarakan Kementerian Hukum dan HAM melalui Badan Pembinaan Hukum Nasional (BPHN) merupakan langkah tepat meskipun secara faktual belum dapat diukur efektifitasnya, sehingga diperlukan kesiapan yang matang bagi BPHN untuk dapat melakukan verifikasi dan akreditasi kepada organisasi bantuan hukum secara tepat, terukur dan terorganisir, yang pada hasilnya nanti tidak menimbulkan persoalan baru berupa kecemburuan bagi organisasi bantuan hukum yang tidak lolos verifikasi, dan membuka peluang bagi mereka untuk mempersoalkan secara hukum, baik dari aspek tata usaha negara maupun aspek hukum lainnya.

\section{E. Penutup}

\section{Kesimpulan}

Berdasarkan pembahasan di atas, dapat diambil kesimpulan bahwa penyelenggaraan Posbakum di Pengadilan Agama Sleman dapat berjalan dengan baik, terbukti dengan banyaknya masyarakat yang memanfaatkan layanan jasa hukum dari Posbakum Pengadilan Agama Sleman, melalui para konsultan hukum yang berasal dari DPW APSI DIY dan LSBH UIN Sunan Kalijaga Yogyakarta. Selama 2 (dua) periode yakni tahun 2011 dan 2012 Posbakum Pengadilan Agama Sleman telah melayani 1.572 orang dengan rincian tahun 2011 sebanyak 699 orang dan tahun 2012 sebanyak 873 orang, dengan penerima bantuan hukum didominasi oleh perempuan sebanyak 1.066 orang sedangkan laki-laki sebanyak 506 orang.

Penyelenggaraan Posbakum di Pengadilan Agama Sleman secara faktual dapat dikatakan 
berjalan efektif. Mayoritas tujuan pemberian bantuan hukum sebagaimana SEMA Nomor 10 tahun 2010 terutama dalam Lampiran B, dapat terpenuhi dengan baik. Hal yang menjadi kelemahan Posbakum Pengadilan Agama Sleman adalah adanya penafsiran yang terlalu luas dalam memaknai 'ketidakmampuan' masyarakat pencari keadilan, di mana pihak Pengadilan Agama Sleman lebih memaknai 'tidak mampu' sebagai tidak mampu 'memahami' prosedur proses peradilan ataupun tidak mampu 'membuat' berkas-berkas pengajuan perkara. Meskipun demikian mengacu indikator efektifitas baik dari sisi substansi kebijakan program, pelaksana program, fasilitas program, dan kesadaran masyarakat pemanfaat program, penyelenggaraan Posbakum di Pengadilan Agama Sleman dapat berjalan efektif.

\section{Saran}

Posbakum akan berjalan dengan lebih efektif, manakala didukung oleh penyediaan anggaran yang dapat digunakan dalam pelaksanaan Posbakum di masa depan, tidak saja terbatas pada pemberi advis atau pembuat berkas tetapi juga turut mendampingi perkara, terutama terkait dengan perkara-perkara yang sangat membutuhkan pendampingan, seperti perceraian karena adanya kekerasan dalam rumah tangga (KDRT), dan perkara urgen lainnya.

Beralihnya kewenangan penyelenggaraan bantuan hukum dari Mahkamah Agung kepada Kementerian Hukum dan HAM seharusnya tidak serta merta meniadakan Posbakum yang telah berjalan. Kementerian Hukum dan HAM dapat meminta Mahkamah Agung melalui badan peradilan di bawahnya untuk secara teknis dapat menyelenggarakan kegiatan bantuan hukum melalui Posbakum dengan menggunakan anggaran yang telah tersedia di Kementerian Hukum dan HAM.

Efektifitas Posbakum di bawah Mahkamah Agung khususnya di Pengadilan Agama, harus menjadi gambaran betapa masyarakat sangat mendambakan kegiatan pemberian bantuan hukum secara cuma-cuma, beberapa hal yang harus diperbaiki hanyalah pada masalah regulasi teknisnya yang terkadang masih membuka peluang bagi munculnya penafsiran. Diperlukan kepastian penafsiran terhadap makna 'masyarakat tidak mampu', apakah hanya tidak mampu secara ekonomi saja dengan dibuktikan adanya surat keterangan tidak mampu (SKTM) atau sejenisnya, atau lebih luas itu, tidak mampu memahami hukum alias 'buta hukum' atau tidak mampu membuat berkas perkara persidangan. Kementerian Hukum dan HAM harus mampu melihat celah-celah yang telah pada penyelenggaraan Posbakum untuk dapat ditutup menjadi suatu kebijakan yang dapat dilaksanakan secara tepat.

\section{DAFTAR PUSTAKA}

\section{Buku}

Soekanto, Soerjono, Suatu Tinjauan Sosiologi Hukum Terhadap Masalah-Masalah Sosial, (Bandung: Alumni, 1982).

\section{Makalah / Artikel / Prosiding / Hasil Penelitian}

Laporan Pos Bantuan Hukum (Posbakum) DPW APSI DIY tahun 2011.

Laporan Pos Bantuan Hukum (Posbakum) DPW APSI DIY tahun 2012.

Laporan Pos Bantuan Hukum (Posbakum) LSBH Fakultas Syariah dan Hukum UIN Yogyakarta tahun 2011.

Laporan Pos Bantuan Hukum (Posbakum) LSBH Fakultas Syariah dan Hukum UIN Yogyakarta tahun 2012.

Prisma No. 6 Tahun II, Desember (1973).

Thalis Noor Cahyadi, Sigiifikansi Ombudsman dalam Penegakan Bisnis Beretika dan Berkelanjutan 
(Studi pada Lembaga Ombudsman Swasta DIY), Riset Sekolah Pascasarjana UGM Yogyakarta, 2010.

\section{Peraturan}

Het Herziene Indonesisch Reglement (HIR).

Undang-Undang Nomor 18 Tahun 2003 tentang Advokat.

Undang-Undang Nomor 4 Tahun 2004 tentang Kekuasaan Kehakiman.

Undang-Undang Nomor 48 Tahun 2009 tentang Kekuasaan Kehakiman.

Undang-Undang Nomor 49 Tahun 2004 tentang Perubahan Kedua Undang-undang Nomor 2 Tahun 1986 tentang Peradilan Umum.
Undang-Undang Nomor 50 Tahun 2009 tentang Perubahan Kedua Undang-undang Nomor 7 Tahun 1989 tentang Peradilan Agama.

Undang-Undang Nomor 51 tahun 2009 tentang Perubahan Kedua atas Undang-undang Nomor 5 Tahun 1986 tentang Peradilan Tata Usaha Negara.

Undang-Undang Nomor 8 Tahun 1981 tentang Hukum Acara Pidana (KUHAP).

Peraturan Pemerintah Nomor 38 Tahun 2008 tentang Persyaratan dan Tata Cara Pemberian Bantuan Hukum.

Surat Edaran Mahkamah Agung (SEMA) Nomor 10 Tahun 2010 tentang Pedoman Pemberian Bantuan Hukum. 